\title{
DOI https://doi.org/10.30525/978-9934-26-116-9-24
}

COSMISATION OF INFORMATION LAW: THE CASE FOR REMOTE SENSING DATA

\author{
Kliapets M. S. \\ Master of Laws \\ Legal Operations Manager at Legal Nodes \\ Kyiv, Ukraine
}

Introduction. It is expected that the value of the space market is going to triple over the next two decades, exceeding the \$1 trillion mark [1]. The growth of the global space value chain capitalization imminently means the increase in the number of space actors and, among others, a logical continuation of the trend of exponential growth of the number of active satellites [2].

The use of space satellites to satisfy information needs (electronic communication, GPS, weather forecasts, Earth data procurement and analysis) leads to the development of space-specific regulations within a usually technologically neutral body of law, Information Law. This process can be referred to as the "cosmisation of Information Law», which shall be the subject of analysis of this conference paper (using remote sensing data as an example).

Materials \& Methods. The empirical basis of this research includes remote sensing regulations (the U.S., the EU, Germany, France, and the UAE), works of legal scholars both in the fields of Information and Space Law, and space sector reports. The following methodology was adopted to examine the nature of the cosmisation of Information Law and its trends in the fields of remote sensing: the hermeneutic and axiological approaches, deductive method, and comparative legal analysis.

Results \& Discussions. 1. Space sector comprises public and private entities, involved in developing, manufacturing, and distributing space products and services. While there is currently no commonly-developed segmentation within the space industry [3, p. 101], activities usually associated with mid- and downstream segments of the space value chain revolve around information, as their infrastructure serves the purpose of space data collection, storage, and processing (midstream segment [4, p. 4]) to provide services or products to end-users (downstream segment [4, p. 4]). This activity can, therefore, be considered an information activity. 
It should be noted that all processes within the information's life cycle (its creation, collection, storage, use, processing, distribution, and protection), as well as everything used for said purposes, are referred to as the «infosphere» [5, p. 15]. Since some space activities are also information activities, the space sector can partially belong to the infosphere but only to the degree where said activities are carried out to satisfy an information need (e.g. to collect Earth data), exercise an information right or obligation, or contribute towards ensuring information sovereignty or security [6, p. 27]. This means that the upstream space segment will fall outside of the infosphere's scope, however accompanying information flows do actually exist within the upstream segment as well, where their functions are secondary (complimentary).

2. An information need is a motivating force behind an action to seek information [7, p. 2453], which comes from perceiving information as a requirement for a person's (or the society's) existence and functioning, as well as the satisfaction of other needs [8, p. 40, 42]. In our opinion, all information needs that are satisfied by carrying out space activities can be classified into two categories:

1) the first category includes information needs satisfied by space exploration. They exist due to curiosity being an imminent characteristic of humanity and their satisfaction enriches the scientific picture of the world;

2) the second category includes information needs satisfied by space exploitation. They exist because of our desire to make life on Earth better and their satisfaction provides us with more effective ways to ecommunicate, predict the weather, or use Earth data to make informed decisions. They are satisfied, inter alia, by the operation of satellites used for remote sensing, which is the process of sensing the Earth's surface from space with electromagnetic waves [9]. Remote sensing data (Earth data) is used, among others, to monitor land and crops, search for natural resources, react to disasters, support logistics, etc.

3. Some countries enacted special laws on remote sensing, which also regulate Earth data flows, therefore partially putting them within the scope of Information Law. Currently, the following legal trends in remote sensing can be identified:

1) emergence of a special information legal regime of space data, including Earth data (the UAE Federal Law № (12) of 2019). Depending on national laws and features of space data, information created during the course of space activities can be public, confidential, or state secret (the U.S. National and Commercial Space Programs Act), or be deemed high-quality (the German $\operatorname{SatDSiG}$ ); 
2) institutionalization of a differentiative approach towards remote sensing data access and distribution depending on which bodies (public or private) financed remote sensing and to which degree (the U.S. National and Commercial Space Programs Act; the ESA's Rules on Information, Data and Intellectual Property);

$3)$ interconnections with open data \& science policies, where remote sensing data can be established to be free for use and distribution (the EU Regulation (EU) 2021/695 \& Regulation (EU) 2021/696);

4) legalization of remote sensing-specific legal statuses for space actors, such as operators or data providers (the German SatDSiG) or space sectorspecific legal statuses, applicable to remote sensing, including primary space data operators (the French $L O I n^{\circ} 2008-518$ du 3 juin 2008). Such statuses include (i) rules for their commencement (receiving permit), (ii) obligations (e.g. to prioritize inquiries of public authorities (Germany), temporarily or permanently seize remote sensing (France: Décret $n^{\circ} 2009-640$ du 9 juin 2009), and (iii) sanctions for violating the law.

In most cases referenced above (excluding open data \& science), specific remote sensing legal provisions also take national interests and sovereignty into account. This approach is understandable since remote sensing activities are not without risks to national security and can somewhat diminish national sovereignty $[10$, p. 213$]$.

4. The term «cosmisation of law» is used to refer to the «process of the transformation of law under new approaches towards the development of a novel concept of the universe's functioning and the understanding of tight bonds between space and the rest of the world $\langle\ldots>\ll[11$, p. 210], including «regulation of $\langle\ldots\rangle$ technical, information, and political issues; addends to national laws and expansion of their scope to include space actors» [12, p. 539].

It should be noted that even without specific regulations for remote sensing or the space sector in general, activities with remote sensing data would fall inside the regulatory scope of Information Law, as all space data is still, in fact, information. Having special laws does, however, help consider objective peculiarities of space activities, such as extreme conditions of outer space, physical characteristics of orbits, limited opportunities for manual repair, and functionality of satellite constellations.

$\mathrm{We}$, therefore, propose to consider the process of developing, enacting, and enforcing space-specific legal norms, to a degree where they regulate the collection, processing, use, or distribution of space data (including Earth data) as a part of the process of cosmisation of Information Law.

Considering the above, let us define the «cosmisation of Information Law» as (i) a part of cosmisation of law within the scope of Information 102 
Law; and (ii) the process of the transformation of Information Law, which is based on seeing space and its exploitation as essential for humanity's existence and development and that manifests in spacespecific norms that regulate how space data can be collected, processed, used, and distributed to satisfy public and private information needs.

Conclusion. The cosmisation of Information Law is a logical legal reformation process, which occurs as a result of the territorial expansion of the infosphere into space and deepens due to the increase in the number of space satellites and space actors. The more information needs are satisfied by space activities and remote sensing in particular, the more vital effective and robust specific regulations for space information infrastructure and the results of its use (space data) are going to become.

\section{References:}

1. Morgan Stanley A New Space Economy on the Edge of Liftoff. URL: https://www.morganstanley.com/Themes/global-space-economy

2. Statista Number of active satellites from 1957 to 2020. URL: https://www.statista.com/statistics/897719/number-of-active-satellitesby-year/

3. Masami Onoda, Oran R. Young Satellite Earth Observations and Their Impact on Society and Policy. Springer Open, 2018. - $221 \mathrm{p}$.

4. PwC Our service offering for the Space sector. URL: https://www.pwc.fr/fr/assets/files/pdf/2018/11/space/pwc-ad-spacesector-2018.pdf

5. Заярний О. А. Правове забезпечення розвитку інформаційної сфери України: адміністративно-деліктний аспект: монографія [Oleh Zaiarnyi Legal Regulation of the Ukrainian Infosphere Development: Administrative Delict Standpoint: monograph]. Helvetyka, 2017. - 700 p.

6. Заярний О. А. Інформаційна сфера як об’єкт адміністративноправової охорони: деякі доктринальні та нормативні аспекти [Oleh Zaiarnyi Infosphere as an Object of Legal Protection in Administrative Law: Some Doctrinal and Legal Aspects]. The Journal of Eastern European Law, 2016. - № 23. - P. 18-31.

7. Charles Naumer \& Karen Fisher Information needs. Encyclopedia of Library and Information Sciences, Third Edition, 2017. - P. 2452-2458.

8. Галета Я. Роль інформаційних потреб у становленні особистості [Yaroslav Haleta The Role of Information Needs in Personality Development]. Volodymyr Vynnychenko Central Ukrainian State «Scientific notes. Series: Pedagogical Sciences», 2015. - № 140. - P. 39-43.

9. Resolution adopted by the General Assembly 41/65. Principles Relating to Remote Sensing of the Earth from Outer Space. 
URL: https://www.unoosa.org/oosa/en/ourwork/spacelaw/principles/remotesensing-principles.html

10. Karen Litfin Satellites and Sovereign Knowledge: remote sensing of the global environment. The Greening of Sovereignty in World Politics, 1998. - P. 193-222.

11. Сорока Л. А. Космізація права [Larysa Soroka Cosmisation of Law]. Scientific Notes. Series: Law, 2019. - № 6. - P. 207-211.

12. Ударцев С. Ф. Космическое государство: предсказуемое направление эволюции государственности [Sergei Udartsev Space State: A Predictable Vector for Statehood Evolution]. XIX International Lykhachev Scientific Readings, 2019. - P. 537-539.

\title{
DOI https://doi.org/10.30525/978-9934-26-116-9-25
}

\section{СУТНІСТЬ ТА ЗНАЧЕННЯ КАСАЦІЙНОГО ПРОВАДЖЕННЯ В АДМІНІСТРАТИВНОМУ СУДОЧИНСТВІ УКРАЇНИ}

\author{
Колеснікова М. В. \\ кандидат юридичних наук, доцент, доцент кафедри \\ адміністративного, господарського права \\ та фінансово-економічної безпеки \\ Навчально-наукового інституту права \\ Сумського державного університету \\ м. Суми, Україна
}

Завданням касаційного провадження, на думку М.М. Ульмара, $\epsilon$ перегляд за касаційною скаргою судових рішень суду першої інстанції після їх перегляду в апеляційному порядку, а також судових рішень суду апеляційної інстанції на предмет правильності застосування норм матеріального і процесуального права, а також правової оцінки обставин у справі. Зазначене свідчить про те, що суд касаційної інстанції перевіряє судові рішення в адміністративній справі щодо правильності застосування судами норм матеріального і процесуального права, а також щодо їх обгрунтованості [1, с. 135].

O.M. Пасинюк зазначає, що порушення або неправильне застосування норм матеріального права полягає у тому, що при прийнятті постанови суд не застосував закон, який потрібно було застосувати, а застосував помилково інший, або ж скасований, або той, який не 